\title{
ATTITUDES OF GREEK UNIVERSITY STUDENTS TOWARDS ENERGY AND THE ENVIRONMENT
}

\section{CHARISIOU N.D. GOULA M.A.*}

\author{
Laboratory of Alternative Fuels and Environmental Catalysis (LAFEC) \\ Pollution Control Technologies Department (PCT) \\ Technological Educational Institute of Western Macedonia (TEI WM)
}

Received: $10 / 10 / 2012$

Accepted: 01/10/2014

Available online: 02/10/2014 *to whom all correspondence should be addressed: e-mail: mgoula@kozani.teikoz.gr

\section{ABSTRACT}

This paper summarises the results of a survey carried out amongst the student population of one of the largest Greek Technological Educational Institutes. It explores attitudes toward the environment in general and then, more specifically, toward global warming and global warming-mitigation technologies. It also explores student understanding of sources of carbon dioxide and climate change-mitigation technologies, such as carbon dioxide capture and storage (CCS). Further, it analyses responses to questions about willingness of respondents to pay to solve global warming. The data was collected in October and November of 2011 using a structured questionnaire which was first formulated in English and then translated into Greek. The analysis was performed using the statistical package SPSS v17.0 and focused on descriptive statistics, in order to compare the average ratings for the different statements.

The present study concludes that university students in Greece are overwhelmingly positively disposed towards the environment with the majority of respondents believing that protecting the environment should have priority over economic considerations. Students also view the effects of global warming as serious enough to warrant action and state their belief that the current generation should meet its own needs without compromising the ability of future generations to meet their own. Moreover, the majority of the participants are against the development of nuclear energy, favoring RES (solar wind and bioenergy), and energy conservation technologies. However, the study has also identified a lack of understanding in regards to sources of carbon dioxide. The majority of the respondents do not seem to know that oceans act as sinks of $\mathrm{CO}_{2}$ emissions or that the housing stock is a significant contributor to this problem.

Keywords: survey, environment, global warming, climate change, university students, Greece

\section{Introduction}

As is well documented, the unprecedented development that the world has experienced since the 1950's has been based upon our insatiable appetite for energy. Although the benefits are obvious, the environmental problems emanating from the use of fossil fuels are of such grave importance that they are increasingly moving towards the top of the international political and economic agenda. Prominent amongst these are the results that anthropogenic greenhouse gas (GHGs) emissions have on the planet's climate. The 2007 Intergovernmental Panel on Climate Change (IPCC) scientific assessment stated with "very high confidence" that humans are having an effect on the climate (IPCC, 2007). The finite nature of the resource is also a cause of anxiety, as is the insecurity surrounding the reliability of 
future energy supplies. The latter is especially prevalent since the terrorist attacks on American soil and the emergence of Asia as a rival center for energy demand. The issue of 'resource nationalism', through the use of National Oil Companies (NOC) has been a matter of bitter debate in the congress of the United States of America (USA). As these were not enough, the majority of oil producing countries are characterized by political instability, while few, are outright hostile towards the 'West'. The recent tragedy in Fukushima, Japan has also highlighted the advantage that Renewable Energy Systems (RESs) have over nuclear energy, namely that of safety. The global strategy to reduce dependence on fossil resources is based on reducing energy consumption, by applying energy savings programs focused on energy demand reduction and energy efficiency in the transportation, industrial and domestic sectors, and by developing and promoting RESs.

Arguably, the European Union (EU) has been one of the most vocal advocates of the need to adopt and implement global schemes that will help reduce GHG emissions, and a driving force behind the conception of the Kyoto Protocol. The development of RES is a core component in the strategies adopted by the EU Member States (MS) to achieve their respective commitments. However, a careful examination of the available data reveals that implementation is still lagging far behind the ideals espoused by policy/ decision makers. Excluding hydro power plants, the share of RES electricity production in 2008, in TWh, was a meager 5.9\% (Table 1). The lion's share is in biomass and wind produced electricity, while geothermal, photovoltaics and tidal/wave have not as yet captured a significant share of the market (Figure 1). Further, RES production in EU MS is characterized by great discrepancies. For example in 2010, Germany and Spain were the largest wind power producers, together accounting for $56.5 \%$ of installed capacity (Figure 2) (EWEA, 2012). It is worth noting that over $75 \%$ of the total off shore wind energy capacity had been installed in the UK and Denmark (KPMG, 2010). Even greater are the discrepancies in electricity produced by photovoltaics, with Germany dominating, with $86 \%$ of the EU total. The failure of the Mediterranean countries to develop this recourse cannot but be noted. A greater variety of MS have developed biomass produced electricity schemes with Germany (19\%), Finland (14\%), the UK (14\%) and Sweden (11\%) as frontrunners. Geothermal and tidal/ wave electricity are almost solely produced by Italy and France respectively (Coenraads et al., 2008; Ruska and Kiviluoma, 2011).

Table 1. EU RES electricity production in TWh in 2008

\begin{tabular}{ccc}
\hline RES Technology & TWh & Share of RES excluding Hydro (\%) \\
\hline Total Biomass & 102,1 & 44,9 \\
\hline Total Hydro & 352 & 0,7 \\
\hline Photovoltaics & 1,5 & 0,0 \\
\hline Solar thermal electricity & 0 & 0,2 \\
\hline Tide \& Wave & 0,5 & 2,4 \\
\hline Geothermal electricity & 5,4 & 51,9 \\
\hline Total Wind & 118 & \\
\hline Total RES & $\mathbf{5 7 9 , 5}$ & \\
\hline RES share of total production (\%) & 14,9 & \\
\hline Total excluding all hydro & 227,5 & \\
\hline RES share of total production & 5,9 & \\
\hline Total electricity produced (RES, & & \\
Conventional sources and \\
Nuclear)
\end{tabular}

Source: Ruska and Kiviluoma, 2011

In Greece, electricity is mainly produced by the use of brown coal (lignite). The utilization of RES begun with the introduction of Law 2773 (1999), which adopted the European directive 1996/92/EC on the liberalization of the electricity markets. As is the case with many EU MS, wind has developed 
significantly better than other RES (70\% of total installed capacity), while PV has only started developing since 2007 (Kambezidis et al., 2011). Arguably, RES development in Greece is lagging far behind its EU partners (excluding large hydro, only $2.6 \%$ of electricity was produced by RES), especially if comparisons are made with the EU-17 (6.2\%).

As a truism, a promising avenue for equipping members of society with the necessary tools for identifying potential solutions to environmental problems can be found in environmental education, as it can produce an environmentally literate citizenry able to actively address relevant challenges and problems. Thus, the investigation of knowledge, perceptions and attitudes, among students of the tertiary sector, that concerns various aspects of environmental issues are of high importance. Such an investigation may reveal the success (or otherwise) of current educational programmes and equip decision makers with the necessary data for the formulation of future policies.

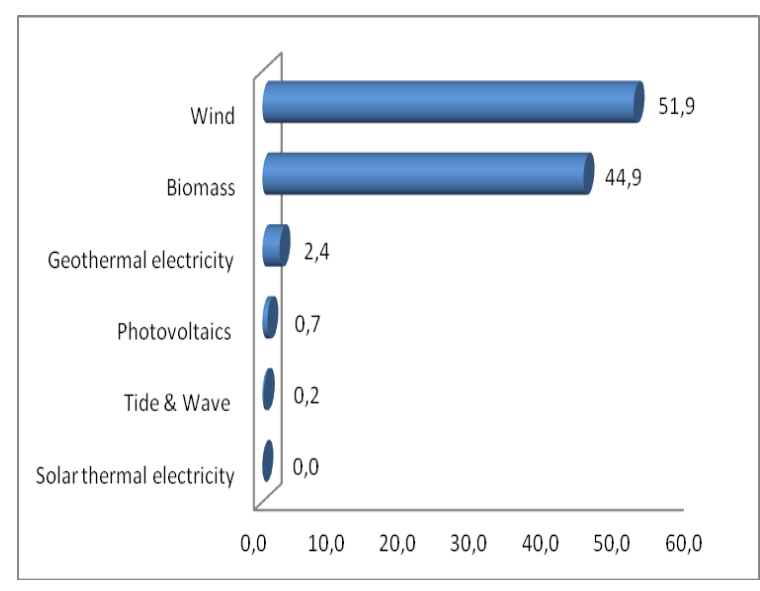

Figure 1. Share (\%) of EU RES production (2008)

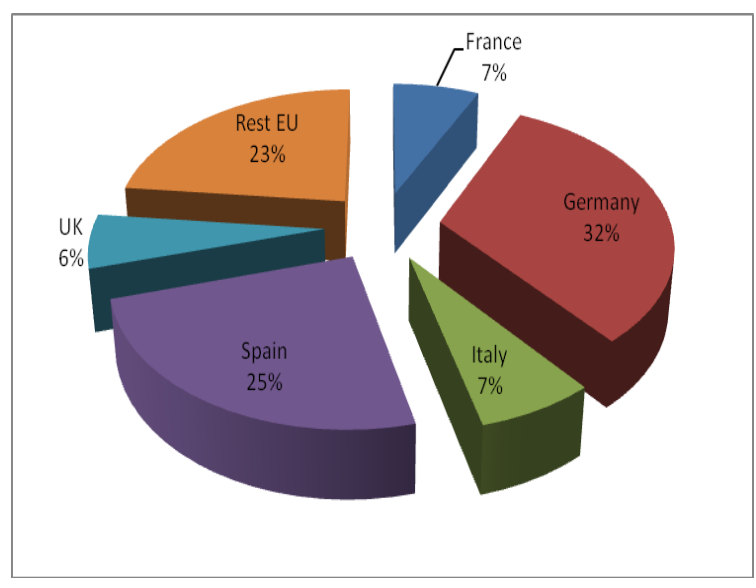

Figure 2. Production of wind energy among EU MS (2010)

This paper summarises the results of a survey carried out amongst the student population of one of the largest Greek Technological Educational Institutes. It explores attitudes toward the environment in general and then, more specifically, toward global warming and global warming-mitigation technologies. It also explores student understanding of sources of carbon dioxide and climate change-mitigation technologies, such as carbon dioxide capture and storage (CCS). Further, it analyses responses to questions about willingness of respondents to pay to solve global warming.

\section{Materials and methods}

\subsection{Questionnaire design}

The data was collected using a structured questionnaire, which consisted of 28 questions. The questionnaire borrowed heavily from a similar study carried out in the UK (Curry et al., 2005), but other studies were also consulted (Gossling et al., 2005; BERR, 2008; Halder et al., 2010; Qu et al., 2011). It was decided to subdivide it into the five following sections:
i. Socio-demographic information (questions 1-12 \& 25)
ii. Attitudes towards environmental issues (questions 13-16 \& 27-28)
iii. Attitudes towards global warming (questions 17-21)
iv. Understanding of carbon dioxide sources (questions 22-23)
v. Willingness to pay (question 24)

The questionnaire was first formulated in English and then translated into Greek. Before the study was conducted the opinions of five experts were sought. Their respective fields of expertise are: 
Environmental catalysis, Wind energy development, Biofuels production, LCA in bioenergy systems and Waste management. Based on the experts recommendations small revisions were made.

\subsection{Data collection}

The survey was conducted in October and November of 2011 at the Technological Educational Institute of Western Macedonia (TEIWM), one of the largest regional Technological Universities in Greece, with 18 departments (providing an equal number of undergraduate courses) and a student population that approaches the 22,000 mark (Table 2). TEIWM is spread over five campuses, which are located in the cities of Kozani, Florina, Kastoria, Ptolemaida and Grevena. The main campus is located in the city of Kozani, which hosts the School of Technological Applications and the School of Management and the Economy, with a total of eight departments. Florina hosts the School of Agricultural Technology with a further three departments. Due to time constrains, no surveys were carried out in the remaining campuses.

Table 2. Information on TEIWM

\begin{tabular}{|c|c|c|c|c|c|}
\hline $\begin{array}{l}\text { Host } \\
\text { city }\end{array}$ & School/ Department & $\begin{array}{l}\text { Numb. } \\
\text { of stud. }\end{array}$ & $\begin{array}{c}\text { Numb. } \\
\text { of } \\
\text { staff }^{1}\end{array}$ & $\begin{array}{l}\text { Numb. } \\
\text { respond. } \\
\text { (\% of } \\
\text { sample) }\end{array}$ & $\begin{array}{l}\text { Contribution of } \\
\text { envir. courses to } \\
\text { the curriculum }\end{array}$ \\
\hline \multirow{11}{*}{$\begin{array}{l}\bar{C} \\
\mathbb{N} \\
\text { O } \\
\underline{y}\end{array}$} & \multicolumn{5}{|l|}{ School of Technological Applications } \\
\hline & Pollution Control Technologies & 1028 & $8(6)$ & $39(9.4)$ & Extreme \\
\hline & Mechanical Engineering & 1472 & $12(12)$ & $76(18.4)$ & Low \\
\hline & Electrical Engineering & 1861 & $11(11)$ & $59(14.3)$ & Low \\
\hline & Industrial Design & 1473 & $6(5)$ & $47(11.4)$ & None \\
\hline & $\begin{array}{l}\text { Geo-technology and the } \\
\text { Environment }\end{array}$ & 1319 & $10(3)$ & $20(4.8)$ & Moderate \\
\hline & Geniko (General) $^{2}$ & 0 & $11(10)$ & - & - \\
\hline & \multicolumn{5}{|c|}{ School of Management and the Economy } \\
\hline & Accounting & 1622 & $7(6)$ & $4(1.0)$ & None \\
\hline & Business Management & 1686 & $6(7)$ & $97(23.4)$ & None \\
\hline & Monetary and Economic Studies & 1091 & $9(4)$ & $20(4.8)$ & None \\
\hline \multirow{4}{*}{$\begin{array}{l}\stackrel{0}{\frac{0}{2}} \\
\frac{0}{4}\end{array}$} & School of Agricultural Technology & & & & \\
\hline & Plant Production & 1473 & $7(4)$ & & None \\
\hline & Animal Production & 864 & $3(4)$ & & None \\
\hline & $\begin{array}{l}\text { Agricultural Products, Marketing } \\
\text { and Quality Control }\end{array}$ & 1010 & $7(4)$ & $50(12.1)$ & None \\
\hline \multirow{4}{*}{ 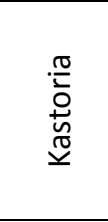 } & Kastoria Campus & & & & \\
\hline & International Trade & 1505 & $6(4)$ & & None \\
\hline & $\begin{array}{l}\text { Public Relations and } \\
\text { Communication }\end{array}$ & 2624 & $3(9)$ & & None \\
\hline & Computer science & 1202 & $7(11)$ & & None \\
\hline \multirow{4}{*}{$\begin{array}{l}\stackrel{0}{\frac{D}{1}} \\
\stackrel{D}{0} \\
\frac{1}{0}\end{array}$} & Grevena Campus & & & & \\
\hline & $\begin{array}{l}\text { Computing Applications in } \\
\text { Management and the Economy }\end{array}$ & 964 & $4(7)$ & & None \\
\hline & Business Computing & 242 & $0(3)$ & & None \\
\hline & Logistics Management & 47 & $0(1)$ & & None \\
\hline \multirow{2}{*}{ Ptol. $^{3}$} & Ptolemaida Campus & & & & \\
\hline & MidWifery & 203 & $0(14)$ & & None \\
\hline Totals & & 21686 & $\begin{array}{c}117 \\
(125) \\
\end{array}$ & 414 & \\
\hline
\end{tabular}

Note: ${ }^{1}$ Non permanent members of staff (adjunct) in parenthesis, ${ }^{2}$ The Geniko department's role is confined to the teaching of basic courses in the first two years of study (e.g., mathematics, chemistry and computers), ${ }^{3}$ Ptolemais 
Two out of the five departments at the School of Technological Applications are wholly (Pollution Control Technologies) or partially (Geo-technology and the Environment) oriented towards environmental studies, however relevant courses (such as Renewable Energy Systems) are taught at another two departments (Mechanical Engineering and Electrical Engineering). A close inspection of the curriculum of the departments belonging to the School of Management and the Economy revealed that environmentally related courses are absent. Surprisingly, given the nature of modern agricultural studies, this was also the case with the departments belonging to the School of Agricultural Technology. The questionnaires were delivered to students in the classrooms. The purpose of the questionnaire was explained, while it was made clear that taking part in the survey was not obligatory. Few declined the opportunity to participate.

Some information regarding the region that TEIWM is located is also necessary, as within Greece, West Macedonia is perceived as suffering from severe environmental degradation. Although no comparable studies exist, it can be expected that this perception may have an influence on the respondents' attitudes towards energy and the environment. West Macedonia is located in the northwest of Greece on the borders of Albania and the Former Yugoslavic Republic of Macedonia (FYROM). The region is mountainous, and geographically isolated. It is classified as a NUTS 2 region, with a per capita income (GDP) of $75 \%$ of the EU average (Eurostat, 2008). Currently, unemployment stands at $24.3 \%$, the highest in Greece (EL.STAT., 2011). Lignite extraction for power production has led to heavy industrialization and the region hosts the largest Greek electricity power production units, which contribute to $50 \%$ of the total electricity production of the country (EL.STAT., 2011). This rapid and unplanned industrialization process has resulted in significant environmental problems and the overreliance of the local economy on the energy sector. It is worth noting that the plumes emanating from the power plants are visible from both the Kozani and Florina campuses.

\subsection{Data analysis}

The analysis was performed using the statistical package SPSS v17.0 and focused on descriptive statistics, in order to compare the average ratings for the different statements.

\section{Results and discussion}

A total of 414 questionnaires were delivered to students in their classrooms. Most participants were male (67.2\%). In terms of age, $61.3 \%$ were between $18-21,26.9 \%$ between $21-24$ and $7.7 \%$ between 24 27. The vast majority stated their nationality as Greek (94.4\%), while $56.2 \%$ classified their place of origin as urban and $43.5 \%$ as rural.

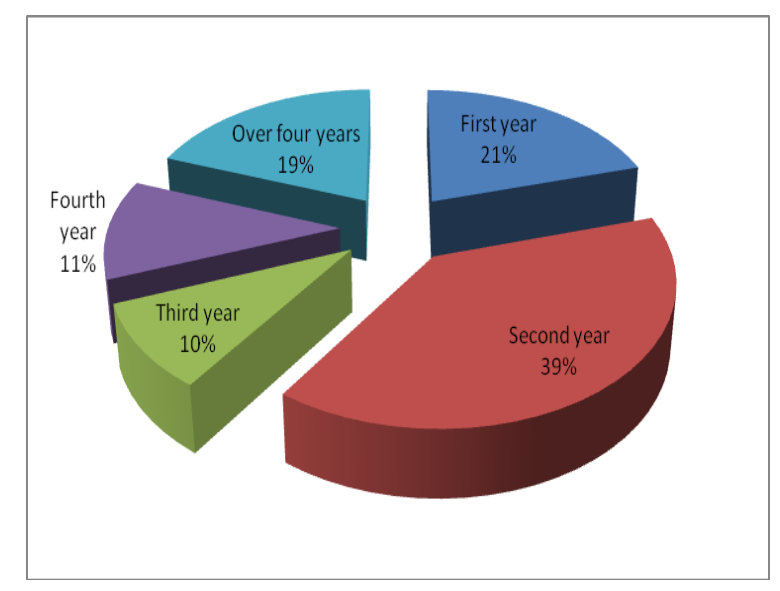

Figure 3. Questionnaire participants by year of study

Most students live on relatively low or modest incomes (for the purposes of the present study, a student's income includes all possible sources, such as money received from parents, employment, 
grants, etc), with $23.6 \%$ on less than $300 €$ per month, $24.1 \%$ between $301-400 €$ and $15.8 \%$ between 401-500€. Very few stated that they have an income greater than $1000 €(2.2 \%)$, while $20.7 \%$ did not wish to divulge that information. Less than a third $(28.3 \%)$ are employed either in full or part time capacity (30.2\% and $69.8 \%$ respectively). Most live alone in rented flats (61.1\%), with student halls $(11.5 \%)$, and at home with parents $(9.8 \%)$ the next highest. For the majority of the respondents the rent paid is between $150-250 €$ (57.6\%), while those in student halls or at home with their parents, live rent free. A breakdown of the respondents by department attended is presented in Table 2 above. Information on the year of study of the participants is presented in Figure 3. It should be noted that all degrees provided by TEIWM are four year courses however, as is common in Greece, a large proportion of students exceeds this time.

A number of questions exploring the attitudes of the respondents towards environmental issues required the choosing of priorities from a given list. For example, in question 13, respondents were asked to choose the three most important issues that Greece is currently facing, from the twenty-four listed in Table 3.

Unsurprisingly for a country caught in the throngs of an economic crisis, unemployment, the economy and tax evasion were all listed among the top four (the issue of tax evasion is currently attracting significant attention in the mass media). The environment was listed as the $10^{\text {th }}$ most important concern. Throughout this study, the $10 \%$ of respondents who included the environment in their top three are considered "concerned about the environment". The survey included a question that explored specific environmental concerns. Participants were asked to select the first and second most important environmental concern facing Greece today. Figure 4 includes both responses. As can be seen, the top three responses were water and soil pollution (35\%), the destruction of ecosystems (30\%) and global warming (22\%). Figure 5 shows the responses to a question that asked participants to choose their preference between protecting the environment and protecting the economy. Encouragingly, the largest percentage of respondents selected a response that said both are important but, given the choice, the environment should take precedence over the economy. No major differences were observed between gender or place of origin. In terms of subject studied, $92 \%$ of the respondents at the Pollution Control Technologies (PCT) believe that highest priority should be given to protecting the environment, even if it hurts the economy. In contrast, only $7 \%$ of those studying Accounting and $9 \%$ of those studying Agricultural Products, Marketing and Quality Control (APMQC) gave a similar answer.

Table 3. Most important issues facing Greece

\begin{tabular}{cccc}
\hline Issue & $\begin{array}{c}\text { Listed amongst top 3 } \\
(\mathbf{\% )}\end{array}$ & Issue & $\begin{array}{c}\text { Listed amongst top 3 } \\
\text { (\%) }\end{array}$ \\
\hline Unemployment & 55 & Income inequality & 6 \\
\hline Education & 37 & Foreign policy & 5 \\
\hline Economy & 34 & Welfare state & 3 \\
\hline Tax evasion & 28 & Terrorism & 3 \\
\hline Asylum seekers & 24 & Keeping the euro & 3 \\
\hline Poverty & 20 & Racism & 3 \\
\hline Health care & 15 & Inflation & 1 \\
\hline Crime & 14 & AlDS & 1 \\
\hline Budget deficit & 11 & Stock market & 1 \\
\hline Environment & 10 & Family values & 1 \\
\hline European Union & 7 & Social exclusion & 1 \\
\hline Drugs & 6 & Aging population & 1 \\
\hline
\end{tabular}




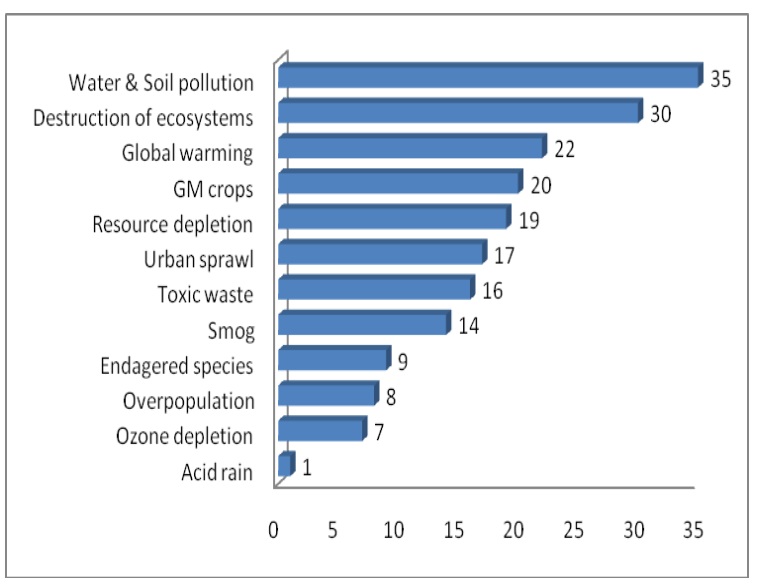

Figure 4. Most important environmental concerns (\%)

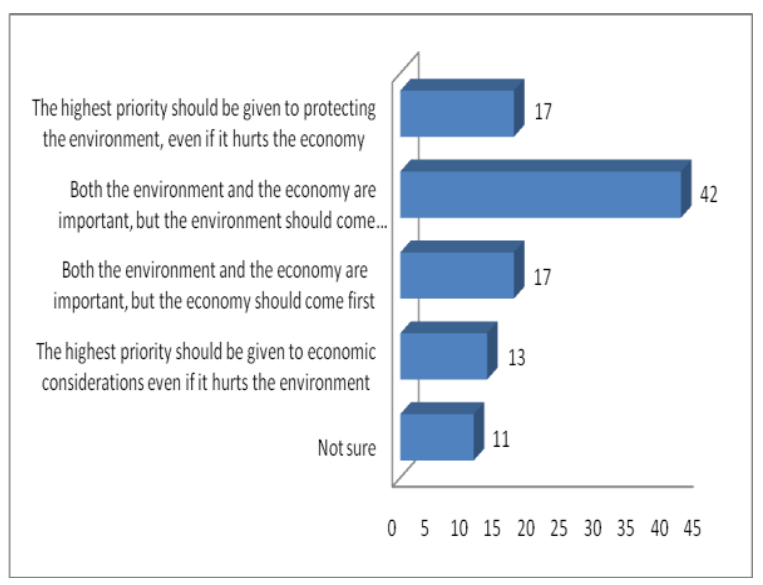

Figure 5. Tradeoffs between the environment and the economy

Although the vast majority of the respondents understand that the operations of automobiles and factories increase $\mathrm{CO}_{2}$ emissions, surprisingly, only $73 \%$ provided the correct answer in regards to coal burning power plants. Even less (44\%), identified home heating as a contributor to $\mathrm{CO}_{2}$ emissions however, this may be attributed to the fact that buildings in the Kozani and Florina cities are heated up by the steam that results from the power plants operating in the area, thus technically, the $24 \%$ that stated that homes have no effect are also correct. Only $12 \%$ of the participants understood that nuclear power stations do neither increase nor decrease $\mathrm{CO}_{2}$. Furthermore, respondents were, in varying degrees, unsure about the effects of farming, trees and oceans (Table 4).

Table 4. Understanding the sources of carbon dioxide

\begin{tabular}{|c|c|c|c|c|c|c|c|}
\hline Technology or practice & $\begin{array}{c}\text { Increases } \\
\mathrm{CO}_{2}(\%)\end{array}$ & $C A^{1}$ & $\begin{array}{c}\text { Decreases } \\
\mathrm{CO}_{2}(\%)\end{array}$ & $C A^{1}$ & $\begin{array}{c}\text { No Effects } \\
(\%)\end{array}$ & $C A^{1}$ & $\begin{array}{c}\text { Not sure } \\
\text { (\%) }\end{array}$ \\
\hline Automobiles & 90 & $\checkmark$ & 3 & & 3 & & 4 \\
\hline Factories & 91 & $\checkmark$ & 6 & & 1 & & 3 \\
\hline Coal burning power plants & 73 & $\checkmark$ & 7 & & 3 & & 16 \\
\hline Home heating & 44 & $\checkmark$ & 4 & & 24 & & 27 \\
\hline Nuclear power stations & 58 & & 10 & & 12 & $\checkmark$ & 19 \\
\hline Farming & 11 & $\checkmark$ & 25 & & 52 & $\checkmark$ & 12 \\
\hline Trees & 6 & & 56 & $\checkmark$ & 34 & & 5 \\
\hline Oceans & 5 & & 37 & $\checkmark$ & 48 & & 10 \\
\hline Windmills & 5 & & 26 & $\checkmark$ & 52 & $\checkmark$ & 17 \\
\hline
\end{tabular}

Note $^{1}$ : CA denotes Correct Answer

The core premise of sustainable development was addressed by asking the participants to respond on whether they believed the present generation has an obligation towards safeguarding the needs of the future generations. $75 \%$ responded positively, while $18 \%$ where not sure (Figure 6). Again, no major differences were observed between gender or place of origin. In terms of subject studied, $98 \%$ of the respondents at the PCT and $87 \%$ of those at Accounting replied positively, while this dropped to $52 \%$, $57 \%$ and $61 \%$ for those at Mechanical, Electrical and APMQC departments respectively.

A number of survey questions explored general attitudes toward global warming. The majority of the respondents (75\%) believe that action to tackle the effects of global warming is necessary, with $2 / 3$ of those advocating immediate action. Only $16 \%$ of the respondents believe that more research is necessary before any action is taken (Figure 7). In terms of likely means to combat global warming, it is interesting to note that over a quarter of the respondents (27\%) believe that although global warming is a problem, Greece will not do anything about it. This may be attributed to current events in the country, 
where the worsening economic situation has led a large number of the populace to doubt the effectiveness of governmental institutions. Nonetheless, $40 \%$ of the participants believe that we will have to change our lifestyles and reduce energy consumption, while a significant proportion (18\%) placed their faith in academic/ research institutes, believing that researchers will develop the necessary tools to combat this issue (Figure 8).

The survey asked respondents to select the technologies they would consider using to address global warming. Each technology was followed by a definition to provide the respondents with information about what they were selecting. The highest preferences included solar, wind and biomass energy, energy efficient cars and appliances and carbon sequestration. Nuclear energy scored lowest, with $61 \%$ being against its development (Figure 9).

The survey also asked respondents to state how much they were willing to pay to address the issue of global warming. Again, it is believed that Greece's economic climate had a large influence on the participants' responses with only $19 \%$ willing to pay more than $20 €$ per month (Figure 10).

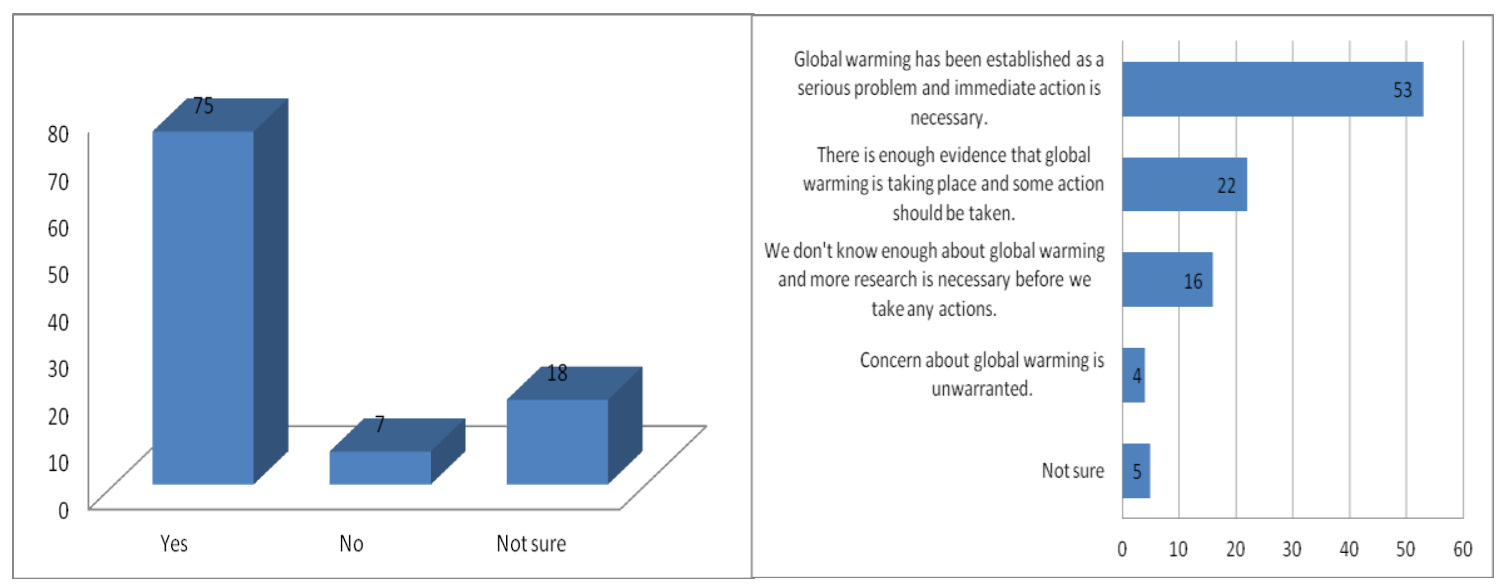

Figure 6. Belief in the obligation towards the needs of future generations (\%)

Figure 7. Opinions about global warming (\%)

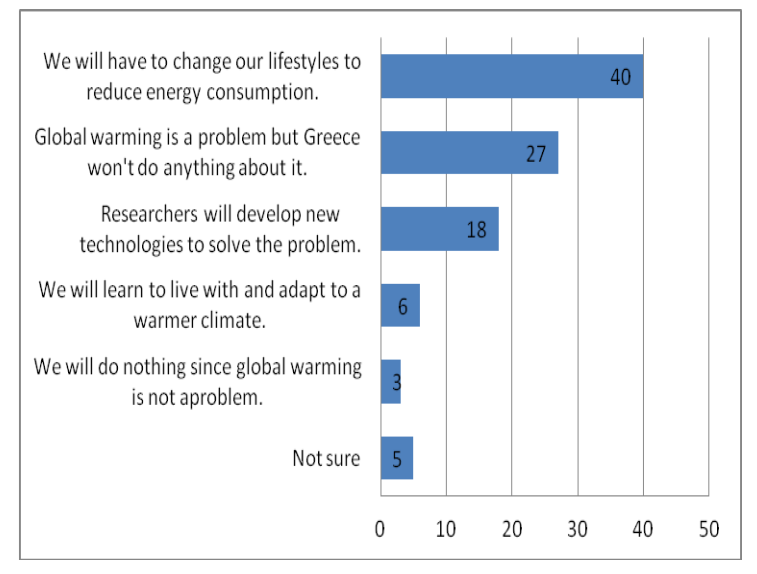

Figure 8. Likely response to global warming (\%) 


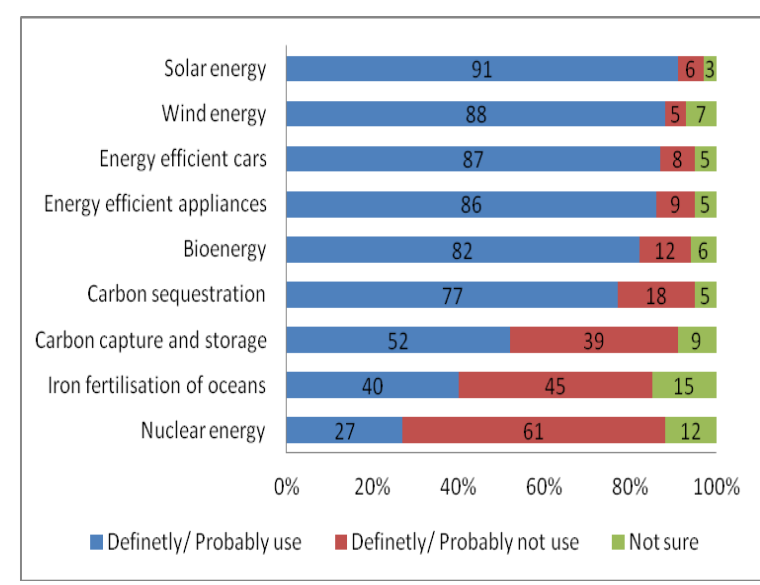

Figure 9. Technological preferences to address global warming

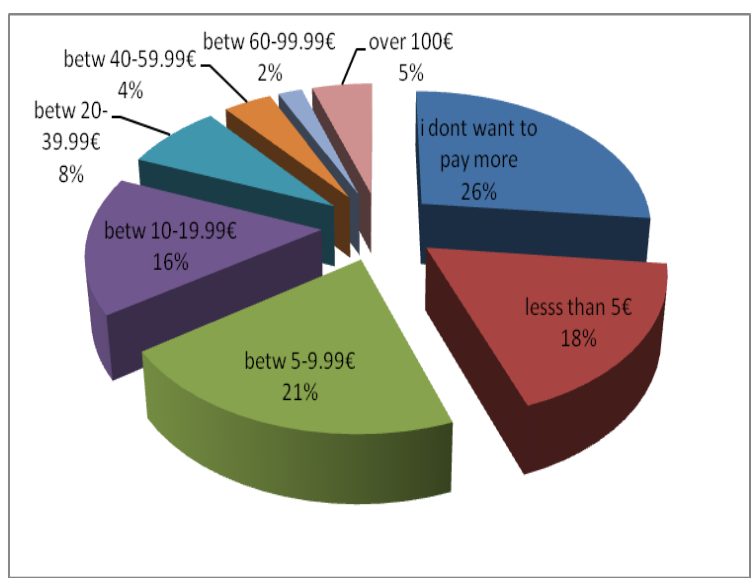

Figure 10. Willingness to pay

\section{Conclusions}

The present study concludes that university students in Greece are overwhelmingly positively disposed towards the environment. It should be noted that most of the students that participated in the survey, study courses that are unrelated to the environment. Thus, despite the fact that the country is currently undergoing a period of harsh austerity measures, with unemployment reaching almost $45 \%$ for those below the age of 35 , the majority of respondents believe that protecting the environment should have priority over economic considerations. Furthermore, they consider that the possible effects of global warming are serious enough to warrant action and state their belief that the current generation should meet its own needs without compromising the ability of future generations to meet their own. Moreover, a significant number accept that a change in lifestyle patterns is necessary in order to reduce our energy consumption. Interestingly, the majority of the participants are against the development of nuclear energy, favoring RES (solar wind and bioenergy), and energy conservation technologies. However, environmental/ educational policy and decision makers should probably ponder over the likely understanding of the younger generation in regards to sources of carbon dioxide. The majority of the respondents do not seem to know that oceans act as sinks of $\mathrm{CO}_{2}$ emissions or that the housing stock is a significant contributor to this problem. This lack of understanding in issues related to GHGs has also been observed by Ikonomidis et. al. (2012) who concluded that Greek prospective primary teachers show serious misconceptions in understanding causes, consequences and possible remediation strategies. Further work should include the crossing of the different demographic characteristics obtained in the first section of the questionnaire, in order to investigate possible explanatory variables. The variables need considering include age, gender, area of origin (rural/urban), study subject and background. Comparisons with similar surveys carried out in different countries will also prove useful.

\section{References}

Business Enterprise and Regulatory Reform, BERR (2008) 'Renewable Energy Awareness and Attitudes Research', Department for Energy and Climate Change, UK.

Coenraads R., Reece G., Kleßmann C., Ragwitz M., Held A., Resch G., Panzer C. and Konstantinaviciute I. (2008), 'Renewable energy country profiles', Final report, Progress project, Contract no. TREN/D1/422005/S07.56988.

Curry T.E., Reiner D.M., de Figueiredo M.A. and Herzog H.J. (2005) 'A survey of public attitudes towards energy and the environment in Great Britain', Laboratory for Energy and the Environment (LFEE), Publication No. LFEE 2005-001 WP, Cambridge, USA. 
European Wind Energy Association (2012) 'Wind in power: 2011 European statistics', http://www.ewea.org/fileadmin/ewea documents/documents/publications/statistics/Stats 2011.pdf (accessed April 12, 2012).

Eurostat (2008), http://epp.eurostat.ec.europa.eu/statistics explained/index.php/GDP at regional level (accessed December 27, 2011).

Gossling S., Kunkel T., Schumacher K., Heck N., Birkemeyer J., Froese J., Naber N. and Schliermann E. (2005), A target group-specific approach to "green" power retailing: students as consumers of renewable energy, Renewable and Sustainable Energy Reviews, 9, 69-83.

Halder P., Pietarinen J., Havu-Nuutinen S. and Pelkonen P. (2010), Young citizens' knowledge and perceptions of bioenergy and future policy implications, Energy Policy, 38, 3058-3066.

Hellenic Statistical Authority, EL.STAT. (2011), http://www.statistics.gr/StatMenu.asp (accessed December 22, 2011) - in Greek.

Hellenic Statistical Authority, EL.STAT. (2011) http://www.statistics.gr/portal/page/portal/ESYE/BUCKET/A0101/PressReleases/A0101_SJO01_DT_QQ 03 201101 F GR.pdf (accessed December 27, 2011) - in Greek.

Ikonomidis S., Papanastasiou D., Melas D. and Avgoloupis S. (2010), The anthropogenic 'Greenhouse Effect': Greek prospective primary teachers' ideas about causes, consequences and cures, Journal of Science Education and Technology, 21, 768-779.

Intergovernmental Panel on Climate Change, IPCC (2007) 'The physical science basis - summary for policymakers', Geneva: IPCC Secretariat.

Kambezidis H.D., Kasselouri B. and Konidari P. (2011), Evaluating policy options for increasing the RES-E penetration in Greece, Energy Policy, 39(9), 5388-5398.

KPMG (2010) 'Offshore wind in Europe: 2010 market report', http://www.kpmg.no/arch/ img/9686536.pdf (accessed April 12, 2012).

Qu M., Ahponen P., Tahvanainen L., Gritten D., Mola-Yudego B. and Pelkonena P. (2011), Chinese university students' knowledge and attitudes regarding forest bio-energy, Renewable and Sustainable Energy Reviews, 15, 3649-3657.

Ruska M. and Kiviluoma J. (2011), 'Renewable electricity in Europe: Current state, drivers, and scenarios for 2020', VTT Research notes 2584, http://www.vtt.fi/publications/index.jsp (accessed March 27, 2012). 